\title{
PKM Kelompok Guru IPA dalam Pembuatan Media Pembelajaran Berbasis Lesson Study di SMP Negeri 16 Mataram
}

\author{
Hikmawati*, A. Wahab Jufri \\ FKIP Universitas Mataram, Mataram, Indonesia
}

\begin{abstract}
Kata Kunci:
Media

Pembelajaran IPA, Lesson Study
\end{abstract}

\begin{abstract}
Abstrak: Laboratorium SMPN 16 Mataram memiliki media pembelajaran untuk mata pelajaran IPA yang masih belum lengkap dan sebagian mengalami kerusakan. Kurangnya media pembelajaran IPA menyebabkan proses pembelajaran IPA menjadi tidak optimal sehingga berdampak pada masih rendahnya hasil belajar peserta didik. Solusi yang ditawarkan melalui kegiatan pengabdian kepada masyarakat ini adalah dengan memberikan pelatihan dan pendampingan bagi guru-guru IPA SMPN 16 Mataram dalam pembuatan media pembelajaran berbasis lesson study. Dalam kegiatan pelatihan dan pendampingan tersebut, dibutuhkan mitra dari sekolah lain yang memiliki Laboratorium IPA yang lebih lengkap, salah satunya yaitu MTsN 1 Mataram. Sistem pelatihan dan pendampingan pembuatan media pembelajaran bagi guru-guru IPA di SMPN 16 Mataram dan MTsN 1 Mataram mengikuti pola lesson study yang setiap siklusnya terdiri atas 3 tahapan yaitu tahap plan, do, dan see. Kegiatan tahap pertama yaitu Tahap "PLAN" sudah dilaksanakan hari selasa, 6 Agustus 2019 bertempat di Sekolah Mitra yaitu SMPN 16 Mataram. Tahap kedua adalah tahap "DO" dan tahap ketiga adalah tahap "SEE" akan segera dilakukan. Pada tahap "DO", guru model akan mensimulasikan penggunaan media pembelajaran yang sudah dibuat bersama guru-guru IPA dari kedua Sekolah Mitra pada siswa dan kelas yang sesungguhnya di SMPN 16 Mataram. Guru-guru IPA lainnya akan bertindak sebagai observer (pengamat) yang akan mengamati aktivitas siswa dalam belajar. Pada tahap ketiga, tahap "See", akan dilakukan kegiatan refleksi yaitu guru model akan menceritakan pengalamannya ketika melaksanakan pembelajaran, sedangkan observer akan memberikan komentar dan saran membangun demi perbaikan proses pembelajaran pada siklus berikutnya. Kegiatan tahap "PLAN" pada pelaksanaan PKM ini diikuti oleh 9 orang guru IPA yang berasal dari kedua Mitra yaitu SMPN 16 Mataram dan MTsN 1 Mataram. Pada tahap pertama ini, kegiatan diawali dengan penyampaian materi oleh Tim PKM tentang lesson study, media pembelajaran IPA, dan teknis pelaksanaan pembuatan media pembelajaran IPA berbasis lesson study. Pada Tahap PLAN ini sudah ditetapkan guru model yang akan simulasi penerapan media yang telah dibuat di kelas sesungguhnya, yaitu Sabtu, 7 September 2019. Media pembelajaran yang dibuat dalam PKM ini sejumlah 5 media yaitu: Papan Eksperimen Hukum Ohm, Papan Eksperimen Hukum Kirchhoff, Mikroskop Digital Portable Auto Design, Penerapan Hukum Pascal, dan Alarm Gempa.
\end{abstract}

\section{Korespondensi: hikmawati@unram.ac.id}

\section{PENDAHULUAN}

\author{
Analisis Situasi \\ Dalam PKM ini, terdapat 2 Sekolah Mitra yang terlibat yakni SMPN 16 Mataram dan \\ MTsN 1 Mataram. Sekolah Mitra 1 adalah SMPN 16 Mataram terletak di Jln. Transmigrasi, \\ Majeluk, Mataram. Sekolah Mitra 2 dalam PKM ini adalah MTsN 1 Mataram, terletak di Jln.
}


Pembangunan B.III Mataram. Berdasarkan Program Kerja Kepala Laboratorium IPA SMPN 16 Mataram Tahun Pelajaran 2017/2018 diperoleh informasi bahwa SMP Negeri 16 Mataram adalah sebuah institusi pendidikan yang dalam pencapaian tujuannya sangat didukung oleh berbagai komponen, salah satunya adalah Laboratorium IPA. Lebih dari itu Laboratorium IPA adalah komponen yang sangat mendasar dalam terlaksananya suatu proses pendidikan untuk mencapai hasil pembelajaran yang lebih baik. Laboratorium adalah tempat pembelajaran sains/IPA dengan cara mencari pengetahuan tentang alam secara sistematis melalui proses penemuan (inquiry) yang menekankan pemberian pengalaman langsung dalam penggunaan dan pengembangan keterampilan proses dan sikap ilmiah peserta didik, yang bermuara pada pembelajaran Work-Based experimen (belajar sambil bekerja). Keberadaan Laboratorium IPA juga perlu didukung oleh sebuah program yang baik agar dapat mencapai tujuan yang direncanakan dan mengacu kepada Visi dan Misi SMPN 16 Mataram.

Permasalahan yang terjadi di SMPN 16 Mataram yaitu Laboratorium IPA memiliki media pembelajaran yang belum lengkap dan sebagian mengalami kerusakan. Kurangnya media pembelajaran IPA menyebabkan proses pembelajaran IPA menjadi tidak optimal sehingga berdampak pada masih rendahnya hasil belajar peserta didik. Berdasarkan hasil observasi dan wawancara Tim Pengusul PKM, materi pembelajaran yang masih belum lengkap media pembelajarannya adalah: pengukuran, tekanan, optik, listrik, dan magnet. Menurut Sukiman (2012), media pembelajaran merupakan segala sesuatu yang dapat digunakan untuk menyalurkan pesan dari pengirim ke penerima sehingga merangsang pikiran, perasaaan, perhatian, dan minat serta kemauan siswa sedemikian sehingga proses belajar terjadi dalam rangka mencapai tujuan pembelajaran secara efektif. Menurut Sudjana \& Rivai (2013), terdapat empat jenis media pembelajaran yakni: (1) media dua dimensi atau media grafis merupakan media yang mempunyai ukuran panjang dan lebar seperti gambar, foto, grafik, bagan atau diagram, poster, kartun, komik, dan lain-lain. (2) media tiga dimensi yaitu dalam bentuk model seperti model padat, model penampang, model susun, model kerja, mock-ups, diorama, dan lain-lain. (3) media proyeksi seperti slide, film strips, film, penggunaan OHP dan lain-lain. (4) lingkungan.

\section{Permasalahan Mitra}

Permasalahan Sekolah Mitra 1 (SMPN 16 Mataram) adalah ketersediaan media pembelajaran IPA dalam Laboratorium yang masih belum lengkap dan sebagian sudah mengalami kerusakan. Kurangnya media pembelajaran IPA tersebut menyebabkan proses pembelajaran IPA di SMP menjadi tidak optimal sehingga berdampak pada masih rendahnya hasil belajar peserta didik.

PKM berupa kegiatan pelatihan dan pendampingan pembuatan media pembelajaran berbasis lesson study ini diharapkan mampu mengembangkan profesionalisme guru-guru IPA di SMPN 16 Mataram maupun di MTsN 1 Mataram. Menurut Hajranul \& Hendayana (2009), Lesson Study (LS) merupakan suatu model pembinaan profesi pendidik melalui pengkajian pembelajaran secara kolaboratif dan berkelanjutan berlandaskan prinsip-prinsip kolegialitas dan saling belajar dengan menguntungkan (mutual learning) untuk membangun komunitas belajar. Cerbin \& Knop (2006) menyebutkan bahwa pendidik yang terlibat dalam pola LS secara langsnung mempraktikkan empati kognitif (cognitive emphaty) dan memfasilitasi peserta didik untuk belajar dan berpikir dengan lebih jelas. Ditnaga Dirjen Dikti (2008) 
menyebutkan bahwa Program pengembangan kompetensi guru MIPA SMP (SISTTEMS) dengan Lesson Study melalui pendampingan guru oleh dosen mengindikasikan terjadinya perubahan sikap positif para guru MIPA, kepala sekolah, dan pengawas.

Mukhtar (2006) mengungkapkan bahwa implementasi Lesson Study di Jurusan Pendidikan Matematika UM memberikan dampak antara lain: 1) peningkatan kolaborasi, kolegialitas, dan komunikasi antara guru dan dosen, 2) implementasi riset pembelajaran menjadi lebih terbuka, 3) dosen di jurusan tersebut mendapat pengalaman langsung berinteraksi dengan guru dan peserta didik di sekolah, dan 4) membantu merevitalisasi asosiasi pendidik Matematika. Pengalaman mengelola penerapan Lesson Study di Jurusan PMIPA FKIP Universitas Mataram menunjukkan bahwa dosen yang ikut membina matakuliah dengan pola ini merasakan adanya manfaat LS terhadap profesionalismenya. Selama dua semester program Lesson Study sekitar 80\% dosen berpendapat bahwa LS memberikan manfaat dalam hal terjadinya peningkatan kemampuan: 1) mengidentifikasi permasalahan pembelajaran MIPA, b) merumuskan alternatif solusi atas permasalahan pembelajaran MIPA, dan c) membentuk komunitas belajar antardosen, antarmahasiswa, dan antara mahasiswa dengan dosen, serta d) meningkatkan efektivitas komunikasi akademik dalam rangka memperbaiki kualitas pembelajaran di jurusan PMIPA FKIP Unram (Laporan LS FKIP Unram, 2010).

Lesson Study dapat diterapkan pada semua jenjang pendidikan dengan berbagai metoda/strategi pembelajaran yang sesuai dengan situasi, kondisi, dan permasalahan yang dihadapi guru. Penerapan LS dapat dipadukan dengan penelitian tindakan kelas (PTK) bagi guru bahkan penelitian tindakan sekolah (PTS) bagi pengawas pendidikan. LS dapat memberikan kontribusi positif terhadap peningkatan kompetensi pendidik, terutama yang terkait dengan pengetahuan tentang materi subyek, pengetahuan pengajaran, pengetahuan riset, kapasitas mengamati siswa, menghubungkan praktik sehari-hari dengan tujuan jangka panjang, motivasi, hubungan dengan kolega dan saling bantu, komitmen, dan akuntabilitas (Lesmini, 2006 dalam Hajranul \& Hendayana 2009).

\section{Solusi Permasalahan}

Solusi permasalahan yang ditawarkan dalam PKM ini adalah dengan memberikan pelatihan dan pendampingan pembuatan media pembelajaran berbasis lesson study bagi guruguru mata pelajaran IPA di kedua Sekolah Mitra. Solusi-solusi yang dimaksud adalah sebagai berikut.

a. Permasalahan: Media pembelajaran di Laboratorium IPA SMPN 16 Mataram belum lengkap dan sebagian mengalami kerusakan

Solusi: Pembuatan media pembelajaran IPA berbasis lesson study. Guru-guru IPA dari kedua sekolah Mitra akan didampingi oleh dosen (tim PKM) dalam pembuatan media pembelajaran serta perangkat pendukung lainnya.

b. Permasalahan: Cara penerapan media pembelajaran IPA berbasis lesson study

Solusi: Simulasi penggunaan media pembelajaran IPA pada siswa dan kelas yang sesungguhnya dengan pola lesson study. Guru model akan melakukan simulasi penggunaan media pembelajaran yang telah dibuat bersama dengan guru-guru IPA dari kedua sekolah mitra 


\section{METODE KEGIATAN}

Metode pelaksanaan kegiatan PKM berupa pelatihan dan pendampingan pembuatan media pembelajaran berbasis lesson study bagi guru-guru IPA di kedua Sekolah Mitra adalah sebagai berikut.

a. Tahap "plan":

- Dosen memberikan ceramah tentang media pembelajaran dan lesson study

- Dosen menunjuk guru model

- Dosen membimbing guru dalam merencanakan pembuatan media pembelajaran serta perangkat pendukung

Partisipasi Mitra:

- Peserta kegiatan pelatihan dan pendampingan pembuatan media pembelajaran berasal dari guru-guru IPA SMPN 16 Mataram dan MTsN 1 Mataram

- Guru model berasal dari salah satu guru IPA di SMPN 16 Mataram

- Guru-guru IPA selain guru model turut membantu membuat media pembelajaran serta perangkat pendukung

b. Tahap "do":

- Guru model melaksanakan pembelajaran dengan siswa dan kelas yang sesungguhnya sesuai yang telah direncanakan pada tahap "plan"

Partisipasi Mitra:

- Siswa dan kelas yang digunakan untuk kegiatan simulasi penggunaan media pembelajaran adalah di SMPN 16 Mataram. Guru model mengajar, sedangkan guru yang lain sebagai pengamat (observer)

c. Tahap "See":

- Kegiatan refleksi

Partisipasi Mitra:

Guru model menceritakan pengalamannya mengajar menggunakan media pembelajaran dan observer memberikan masukan/komentar.

\section{HASIL DAN PEMBAHASAN}

Pelaksanaan kegiatan PKM tahap PLAN telah dilaksanakan pada hari selasa, 6 Agustus 2019 yang bertempat di SMPN 16 Mataram. Kegiatan tahap PLAN ini diikuti oleh 9 guru IPA, 1 orang teknisi, dan Kepala Sekolah SMPN 16 Mataram.

Pada tahap PLAN, kegiatan diawali dengan penyampaian materi oleh Tim PKM tentang:

1. Lesson Study

2. Media Pembelajaran IPA

3. Teknis pelaksanaan Pembuatan Media Pembelajaran IPA berbasis Lesson Study

Setelah penyampaian materi, peserta didampingi untuk pemilihan guru model dan media pembelajaran IPA yang akan dibuat, serta penentuan waktu pelaksanaan tahap kedua (tahap "DO"). Pada tahap pertama ini diperoleh kesepakatan media pembelajaran yang akan dibuat terdiri atas 5 macam media yaitu: Papan Eksperimen Hukum Ohm, Papan Eksperimen Hukum Kirchhoff, Mikroskop Digital Portable Auto Design, Penerapan Hukum Pascal, dan Alarm Gempa. Pembuatan media pembelajaran ini sesuai dengan hasil observasi di sekolah 
Mitra tentang materi pembelajaran yang masih belum lengkap media pembelajarannya yaitu: pengukuran, tekanan, optik, listrik, dan magnet.

Papan Eksperimen Hukum Ohm dapat membantu guru menjelaskan konsep bahwa arus pada kawat logam sebanding dengan beda potensial (tegangan) yang diberikan ke ujungujungnya. Besarnya aliran arus pada kawat tidak hanya bergantung pada tegangan, tetapi juga pada hambatan yang diberikan kawat terhadap aliran elektron. Elektron-elektron diperlambat karena adanya interaksi dengan atom-atom kawat. Makin tinggi hambatan ini, makin kecil arus untuk suatu tegangan.

Papan Eksperimen Hukum Kirchoff dapat membantu guru menjelaskan konsep bahwa pada setiap titik cabang, jumlah semua arus yang memasuki cabang harus sama dengan semua arus yang meninggalkan cabang tersebut. Konsep lain yang dapat dijelaskan dengan papan eksperimen ini adalah jumlah perubahan potensial mengelilingi lintasan tertutup pada suatu rangkaian harus nol.

Mikroskop Digital Portable Auto Design memanfaatkan smartphone sebagai layar untuk mengamati objek yang ingin diamati. Tersedianya banyak aplikasi dalam play store memungkinkan smartphone dapat terhubung tanpa kabel dengan Laptop/LCD sehingga objek yang ingin diamati dengan mikroskop tersebut dapat diamati secara bersama-sama melalui layar LCD. Mikroskop yang memanfaatkan jaringan WIFI ini memiliki pembesaran sampai 167,64 kali. Tersedianya sumber cahaya yang lengkap pada media modern ini menjadikan pengguna dapat memakainya diberbagai lokasi (dalam kelas atau luar kelas). Adanya sumber cahaya tersebut membuat para pengguna menjadi lebih mudah dalam menggunakan media tersebut, kemudahan yang dimaksud seperti tidak bergantung pada terang gelapnya ruangan/tempat, objek yang diamati tidak perlu ditipiskan, dan dapat mengamati benda apa saja yang ada di sekitar lingkungan sekolah.

Media Penerapan Hukum Pascal yang dihasilkan dalam kegiatan PKM ini dapat menjelaskan konsep bahwa setiap kenaikan tekanan pada permukaan fluida (zat cair), harus diteruskan ke segala arah fluida tersebut. Media alarm gempa dapat menjelaskan konsep tentang getaran, gelombang, bunyi dan arus listrik.

Adapun tahap "DO" akan dilakukan pada sabtu tanggal 7 September 2019, mulai pukul 07.30 Wita. Tahap ketiga (tahap "SEE") akan dilakukan segera setelah pelaksanaaan tahap"DO".

\section{KESIMPULAN DAN SARAN}

Pelaksanaan PKM Kelompok Guru IPA dalam pembuatan media pembelajaran berbasis lesson study di SMP Negeri 16 Mataram telah mampu mengembangkan keterampilan peserta kegiatan dalam pembuatan media pembelajaran. Hal ini diharapkan dapat memberikan dampak terhadap peningkatan hasil belajar peserta didik.

\section{DAFTAR PUSTAKA}

Sukiman. 2012. Pengembangan Media Pembelajaran. Yogyakarta: Pustaka Insan Madani.

Sudjana, N., \& Rivai, A. 2013. Media Pengajaran (penggunaan dan Pembuatannya). Bandung: Sinar Baru Algensindo. 
Cerbin, William and Bryan Kopp. 2006. Lesson Study as a Model for Building Pedagogical Knowledge and Improving Teaching. International Journal of Teaching and Learning in Higher Education 2006, Volume 18, No. 3, 250-257 (Online): http://www.isetl.org/ijtlhe. Diakses 12 Januari 2011.

Ditnaga Dikti. 2008. Buku Panduan Pelaksanaan Lesson Study di LPTK. Program Perluasan Lesson Study untuk Penguatan LPTK (Lesson Study Dissemination Program for Strengthening Teacher Education in Indonesia - LEDIPSTI).

FKIP Unram. 2010. Laporan Pelaksanaan Program Perluasan dan Penguatan Lesson Study. Dibiayai Hibah dari Direktorat Ketenagaan Dirjen DIKTI.

Hadjranul, Abdul dan Hendayana Sumar. 2010. Applied Lesson Study at Experiment Chemistry Learning Based on Local Material. Proceeding of the Third International Seminar on Science Education, Challenging Science education in the Digital Era. Bandung.

Muchtar Abdul Karim. 2006. Implementation of Lesson Study for Improving the Quality of Mathematics Instruction in Malang. Tsukuba Journal of Educational Study in Mathematics. Vol.25, p: $67-73$. 